\title{
In vitro conservation of Amburana cearensis (Fabaceae)
}

\section{Bruno Freitas Matos Alvim ${ }^{1}$ (D) Ana Valéria Vieira de Souza $^{2}$ (D) Alone Lima-Brito ${ }^{3}$ (D) Priscila Tavares Fonseca ${ }^{1}$ (D) Taliane Leila Soares ${ }^{1 *}$ (D) José Raniere Ferreira de Santana ${ }^{3}(D)$}

${ }^{1}$ Programa de Pós-graduação em Recursos Genéticos Vegetais, Universidade Estadual de Feira de Santana (UEFS), 44036-900, Feira de Santana, BA, Brasil. E-mail: talialeilla@gmail.com. "Corresponding author.

${ }^{2}$ Embrapa Centro de Pesquisa Agropecuária Trópico Semiárido (CPATSA), Petrolina, PE, Brasil.

${ }^{3}$ Departamento de Ciências Biológicas, Universidade Estadual de Feira de Santana (UEFS), Feira de Santana, BA, Brasil.

ABSTRACT: Slow-growth tissue culture allows in vitro conservation of plant genetic resources and is a complementary technique to conventional preservation methods. The objective of this study was to evaluate the effect of the culture medium supplemented with sucrose, mannitol and sorbitol osmotic agents on the induction of in vitro slow growth of A. cearensis, seeking to establish alternative techniques for ex situ conservation of the species. Plants with age of 10 days were inoculated in woody plant medium (WPM) supplemented with different concentrations of sucrose $(87.64,131.46,175.28$ or $262.92 \mathrm{mM}$ ) combined with mannitol or sorbitol at varying concentrations (0.0, 43.8 , 65.73, 87.64 or $131.46 \mathrm{mM}$ ), solidified with $0.7 \%$ agar. The following parameters were evaluated: survival percentage, number of senescent leaves, aerial part length, root length, aerial part dry mass, root dry mass; and number of shoots. The conservation of A. cearensis was viable for up to 300 days in WPM supplemented with $262.92 \mathrm{mM}$ of sucrose or the combination of $87.64 \mathrm{mM}$ of sucrose with $43.80 \mathrm{mM}$ of mannitol, because besides achieving a survival percentage greater than $55.0 \%$, the plants conserved in these media presented normal development and the best appearances, with predominance of uniform green leaves during the storage process.

Key words: slow growth, osmotic agent, growth retardant, cumaru, conservation of germplasm.

\author{
Conservação in vitro de Amburana cearensis (Fabaceae)
}

RESUMO: A cultura de tecidos, através do crescimento mínimo, possibilita a conservação in vitro dos recursos genéticos vegetais, tornandose uma técnica complementar aos métodos convencionais de conservação. O objetivo deste estudo foi avaliar o efeito do meio de cultura suplementado com sacarose, manitol e agentes osmóticos sorbitol na indução de crescimento mínimo in vitro de A. cearensis, buscando estabelecer técnicas alternativas para conservação ex situ da espécie. Plantas com 10 dias foram inoculadas em meio de cultura WPM suplementado com diferentes concentrações de sacarose (87,64; 131,46; 175,28 e 262,92 mM) combinado com manitol ou sorbitol nas concentrações $(0,0 ; 43,8 ; 65,73 ; 87,64$ e 131,46 mM), solidificados com 0,7\% de ágar. Foram avaliados a porcentagem de sobrevivência, número de folhas senescentes, comprimento da parte aérea, comprimento da raiz, massa seca da parte aérea, massa seca da raiz e número de brotos. A conservação de A. cearensis mostrou-se viável até 300 dias, em meio de cultura WPM suplementado com 262,92 mM de sacarose ou na combinação de $87.64 \mathrm{mM}$ de sacarose com $43.80 \mathrm{mM}$ de manitol. Assim sendo, além de apresentarem porcentagem de sobrevivência acima de $55.0 \%$, as plantas conservadas nesses meios apresentaram um desenvolvimento normal e com melhores aparências com predomínio de folhas verdes uniformes ao longo do processo de armazenamento.

Palavras-chave: crescimento mínimo, agente osmótico, retardante de crescimento, cumarú, conservação de germoplasma.

\section{INTRODUCTION}

Amburana cearensis (Allemão) A.C.Smith. (Fabaceae) is a species native to the Brazilian semiarid region, especially the Caatinga (seasonally dry shrubland) biome (PEREIRA et al., 2017), popularly known as 'imburana de cheiro', 'amburana de cheiro' or 'cumarú' (CAMPO et al., 2013). Different parts of this plant, such as leaves, stems and seeds, are widely used in folk medicine and have been confirmed to have multiple medicinal applications (SÁ et al., 2014; LATALIZA et al., 2019; PEREIRA et al., 2017). Besides this, A. cearensis is known for its wood quality and as an ornamental plant and source of forage (CAMPOS et al., 2013). 
The growing economic demand for cumarú as a source of wood and medicinal substances is mainly satisfied by extractivism that can be classified as predatory, posing a threat to its survival. As a result, Amburana cearensis has been classified as endangered according to the International Union for the Conservation of Nature (IUCN, 2019).

Therefore, urgent measures are necessary to preserve the species. The application of tissue culture techniques has enabled in vitro active germplasm banks of various species, such as Curcuma longa and Zingiber officinale (JAIN et al., 2018), Polygonum multiflorum Thunb (HUANG et al., 2014), Solanum lycopersicum L. (AL-ABDALLAT et al., 2017) and Salix tetrasperma Roxb. (KHAN et al., 2018). These have advantages over ex vitro germplasm banks, among them maintenance of many accessions in a small physical space and freedom from bad weather in open fields or conditions in covered spaces or greenhouses. Although, the in vitro multiplication of $A$. cearensis has been studied (CAMPOS et al., 2013) to enable large-scale production of seedlings, to date no information is available on the in vitro conservation of this species.

One of the ways to conserve plant matter is by slow growth in culture media, a method of ex situ conservation that reduces the plants' metabolism, by chemical and/or physical modifications in the medium or culture conditions (AL-ABDALLAT et al., 2017; ATTIA et al., 2018; MUÑOZ et al., 2019).

The use of osmotic agents like sucrose, sorbitol and mannitol reduces the water potential of the medium, limiting the water availability and thus restricting the uptake of nutrients and the metabolic activity of the cells (HUANG et al., 2014). This conservation strategy has several advantages, such as longer times between subcultures, reduced costs to maintain the germplasm bank and lower risk of somaclonal variation (CHAUHAN et al., 2016).

A previous study conducted by LEITE et al. (2005) about the state of knowledge regarding $A$. cearensis for genetic conservation in Brazil reported that actions for ex situ conservation are highly recommended for specific parts, in places where loss of resources is already so extensive that in situ measures by themselves are not sufficient.

Therefore, it is necessary to establish a protocol for in vitro conservation of Amburana cearensis, as an alternative way of germplasm preservation. The objective of this study was to evaluate the effect of the culture medium supplemented with sucrose, mannitol and sorbitol osmotic agents on the induction of slow growth in vitro of $A$. cearensis, seeking to establish alternative techniques for ex situ conservation of the species.

\section{MATERIALS AND METHODS}

\section{Explant collection and surface disinfestation}

The experiments were performed in the Plant Tissue Culture Laboratory (LCTV), belonging to the Experimental Forest Plantation Unit of Universidade Estadual de Feira de Santana, located in the municipality of Feira de Santana, Bahia.

A. cearensis seeds were collected in a Caatinga area located near the experimental farm of the Embrapa Semiárido research unit, in Petrolina, Pernambuco, Brazil. Seeds were placed in kraft paper bags and stored in a cold chamber, where they remained until the start of the experiment.

To obtain the plants in vitro, seeds were washed in running water for 10 minutes, followed by disinfestation in a laminar flow chamber with immersion in $70 \%$ ethanol for 1 minute followed by a solution of sodium hypochlorite $(\mathrm{NaOCl})$ [commercial bleach $-2.5 \%$ active chlorine] with 2 droplets of neutral detergent for 10 minutes. Seeds were washed four times in sterile distilled water and inoculated in tubes containing $15 \mathrm{~mL}$ of culture medium, according to the method described by CAMPOS et al. (2013).

\section{Culture media and conditions \\ The woody plant medium (WPM) of} LLOYD \& MCCOWN (1980) was used in all the experiments, solidified with $0.7 \%$ agar. The $\mathrm{pH}$ of the medium was adjusted to $5.7 \pm 0.1$ before autoclaving. After that, the culture medium was distributed in test tubes $(25 \times 150 \mathrm{~mm})$ sealed with plastic lids and sterilized by autoclaving for 15 minutes at temperature of $121^{\circ} \mathrm{C}$ and pressure of $1 \mathrm{~atm}$.

\section{Slow-growth storage strategy}

The germinated plantlets with 10 days of age were inoculated in new test tubes $(25 \mathrm{~mm} \times 150$ $\mathrm{mm}$ ) containing $15 \mathrm{~mL}$ of WPM supplemented with different concentrations of sucrose $(87.64,131.46$, 175.28 or $262.92 \mathrm{mM}$ ) combined with mannitol or sorbitol, at varied concentrations $(0.0,43.8,65.73$, 87.64 or $131.46 \mathrm{mM}$ ), totaling 12 treatments, as described in the table 1 .

The survival percentage ( $\%$ SURV) was evaluated every two months to ascertain the interaction of the factors culture time $\mathrm{x}$ concentration of osmotic agent. At 300 days after the start of the experiment, the following variables were recorded: 
Table 1 - Osmotic treatments used for in vitro conservation of Amburana cearensis (Fabaceae) using woody plant medium (WPM).

\begin{tabular}{lccc}
\hline Medium names & & & \\
& & & \\
M1 & Sucrose & Sorbitol & Mannitol \\
M2 & 87.64 & 0 & 0 \\
M3 & 131.46 & 0 & 0 \\
M4 & 175.28 & 0 & 0 \\
M5 & 262.92 & 0 & 0 \\
M6 & 87.64 & 0 & 43.80 \\
M7 & 131.46 & 0 & 65.73 \\
M8 & 175.28 & 0 & 87.64 \\
M9 & 262.92 & 0 & 131.46 \\
M10 & 87.64 & 43.80 & 0 \\
M1 & 131.46 & 65.73 & 0 \\
M12 & 175.28 & 87.64 & 0 \\
\hline
\end{tabular}

number of senescent leaves, aerial part length ( $\mathrm{mm})$, aerial part dry mass $(\mathrm{mg})$, root dry mass $(\mathrm{mg})$ and number of shoots.

The cultures were kept in a growth room under controlled conditions of temperature $(25 \pm 2$ $\left.{ }^{\circ} \mathrm{C}\right)$, photoperiod $(16 / 8 \mathrm{~h})$ and photosynthetically active radiation $\left(60 \mu \mathrm{mol} . \mathrm{m}^{-2} \cdot \mathrm{s}^{-1}\right)$ supplied by cool white fluorescent lamps. The experimental design was completely randomized with six repetitions per treatment, each composed of five experimental units.

\section{Data analysis}

For statistical analysis, the survival percentage data were transformed into arcsine $(\sqrt{x / 100})$ for normalization and homogenization of the variances and then submitted to analysis of variance (ANOVA), and the means value treatments were compared by the Scott-Knott test at 5\% probability. All the statistical procedures were performed with the SAS 9.3 software (SAS Institute, Cary NC).

\section{RESULTS AND DISCUSSION}

To retard the in vitro survival and vegetative development of $A$. cearensis, we investigated the effect of the sorbitol, mannitol and sucrose (osmotic sucrose) in the culture medium (Table 1). The survival percentage was significantly higher $(100.0 \%)$ in the first four months (120 days of storage) (Figure 1). However, the percentage of surviving plants decreased significantly $(\mathrm{p} \leq 0.05)$ after 120 days. This reduction was greater at the end of the experiment (10 months), in the presence of higher concentrations of sucrose, sorbitol or mannitol, as observed in M8 and M12, with $0.0 \%$ and $10.0 \%$ survival, respectively. Osmotic agents acted as growth retardants by causing osmotic stress to the material under conservation (EL-BAHR et al., 2016).

These carbohydrates reduced the water potential and the availability of water to the explants (HUANG et al., 2014). Osmotic agents like mannitol and sorbitol reduced the absorption of minerals by the cells by means of different osmotic pressures, thus retarding plant growth (TAVAZZA et al., 2015; MUÑOZ et al., 2019). In this context, mannitol, sucrose and sorbitol have been reported to prolong the useful lifetime of in vitro cultured tissues (SHARAF et al., 2012). We observed that the amburana plants conserved for 300 days in culture media containing $262.92 \mathrm{mM}$ of sucrose (M4) showed a higher survival percentage (Figure 2A); although, it did not differ from the medium containing $87.64 \mathrm{mM}$ of sucrose and $43.8 \mathrm{mM}$ of mannitol (M5). Conversely, plants grown in culture media containing $262.92 \mathrm{mM}$ of sucrose supplemented with $131.46 \mathrm{mM}$ of mannitol (M8) or sorbitol (M12) presented the lowest survival rates or even death of all plants (Figure 2B).

Other studies have demonstrated that the presence of sorbitol and/or mannitol combined with sucrose in the conservation medium increased the survival percentage of various plant species (TAVAZZA et al., 2015; TAKUR et al., 2015; EL-BAHR et al., 2016; NASIRUDDIN AND ISLAM, 2018).

Regarding the number of senescent leaves, it increased in plantlets grown with the smallest concentration of sucrose $(87.6 \mathrm{mM})$, as well as when 


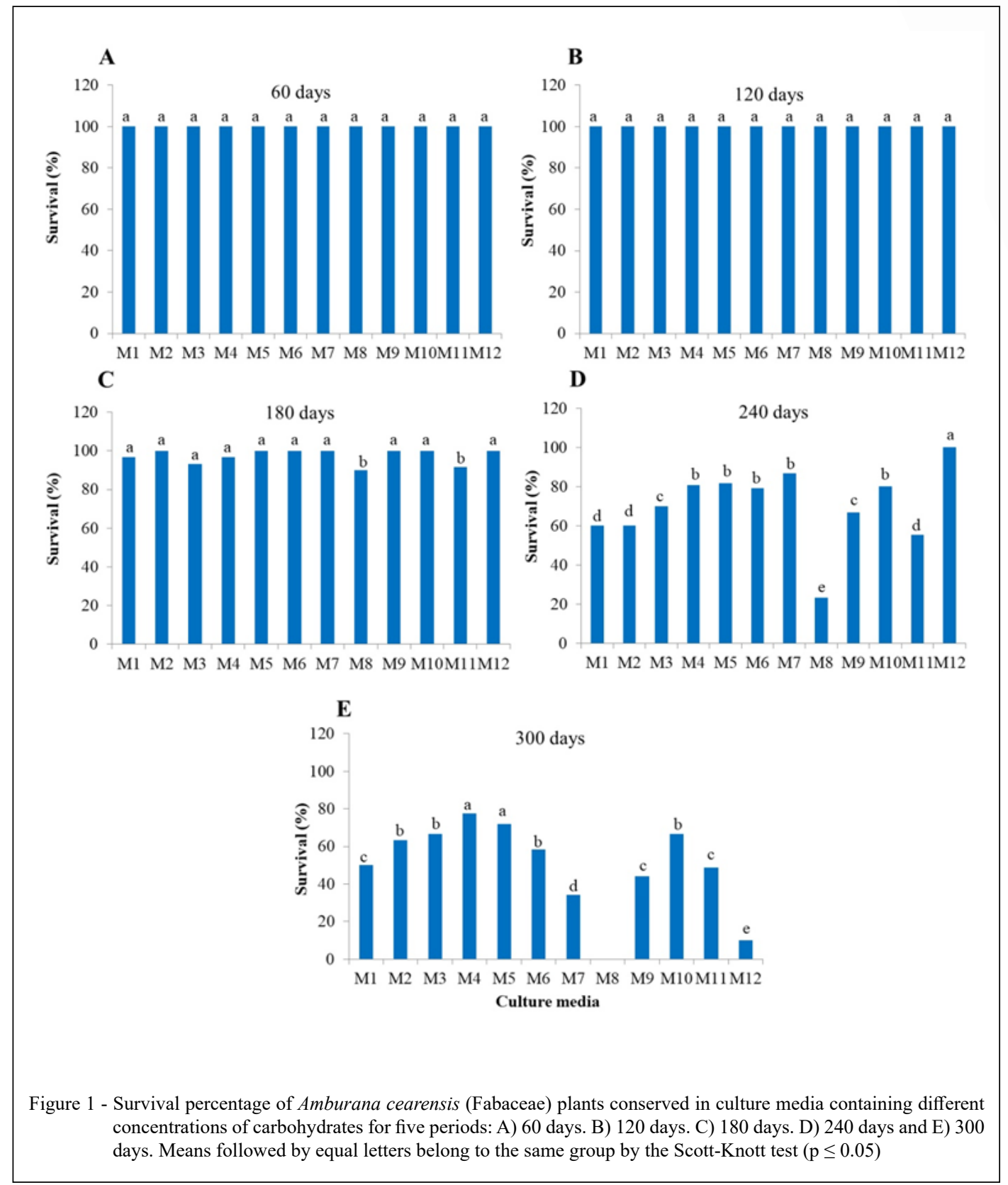

combined with $43.8 \mathrm{mM}$ of sorbitol (M9) (Figure $3 \mathrm{~A}$; Figure 2C). This can be explained by the fact that alcohol sugars at low concentrations do not act as reducers of the water potential, thus decelerating the plant growth. However, the lowest number of senescent leaves was observed in the plants grown in media supplemented only with sucrose at the highest concentration $(262.92 \mathrm{mM})$, or combined with mannitol and sorbitol, except for M5 and M9, containing $43.8 \mathrm{mM}$ of these osmotic agents. (Figure
3A). Plants in treatment M12 did not have any leaves with signs of senescence, despite the low survival rate obtained in this culture medium after 300 days.

Some authors have stated that in vitro senescence can be attributed to exhaustion of the nutritive capacity of the culture medium, accumulation of inhibitory products resulting from cell metabolism and/or toxicity of the medium after long periods because of evaporation of water from the tubes (GRATTAPAGLIA \& MACHADO, 1998). 


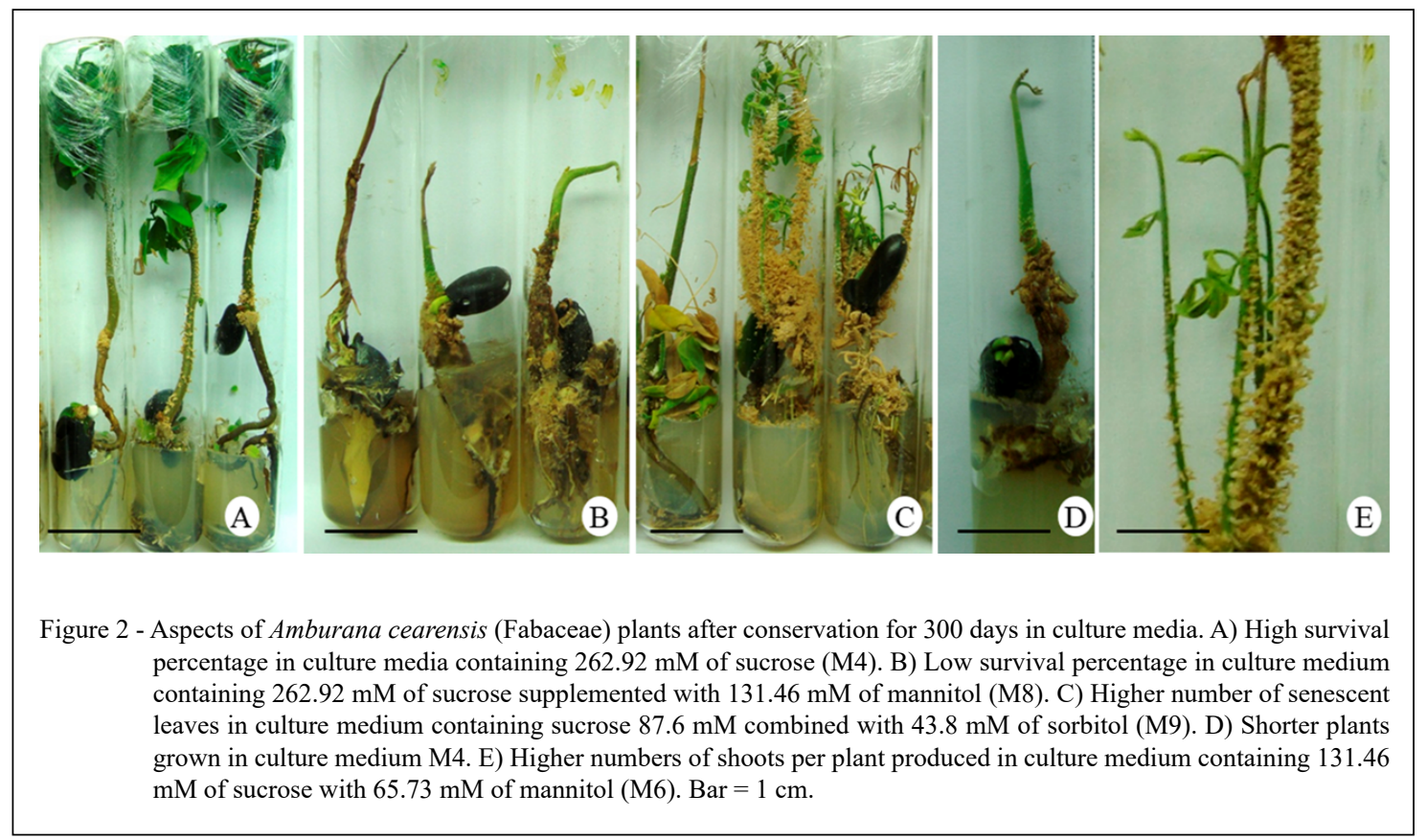

In particular, the accumulation of substances from metabolism is caused by the fact the test tubes are closed, limiting the gas exchanges with the external environment and preventing the release of toxic compounds such as ethylene. This, in turn, is strongly indicated by the presence of fallen leaves from the cultured plants. Therefore, the accumulation of this plant regulator can affect the morphogenesis of the cultures, accelerating the senescence and inducing foliar abscission (GRATTAPAGLIA \& MACHADO, 1998; NEPOMUCENO et al., 2009).

For aerial part length, the culture medium supplemented with sucrose at concentration of 175.28 $\mathrm{mM}$ (M3) promoted the highest average, of $94 \mathrm{~mm}$ (Figure 3B). However, when this carbohydrate was used at the highest concentration $(262.92 \mathrm{mM})$ in the medium (M4), the smallest length was observed (Figure 2D). This result can be explained by the fact that sucrose at high concentrations acts as an osmotic agent, reducing the water potential of the medium and thus hindering the absorption of water and nutrients (JO et al., 2009; CUI et al., 2010; SUMARYONO et al., 2012).

The presence of sucrose, sorbitol or mannitol in the culture medium had a negative effect on the aerial part development. This reduction was most pronounced in the presence of higher concentrations of sucrose $(262.92 \mathrm{mM})$ and sorbitol $(131.46 \mathrm{mM})$ $(21 \mathrm{~mm})$; although, this treatment belongs to the same group as M6 (131.46 mM of sucrose $+65.73 \mathrm{mM}$ of mannitol) and M7 (175.28 mM of sucrose +87.64 $\mathrm{mM}$ of mannitol) (Figure 3B).

High osmotic pressure acts to suppress the metabolism of plants (CUI et al., 2010), a fact reflected in the lower growth of aerial part of A. cearensis. These results are partially concordant with those obtained by TAVAZZA et al. (2015), who observed a reduction of the aerial part length of artichoke plants (Cynara cardunculus var. scolymus L.) cultivated in the presence of mannitol, while in the medium supplemented with sucrose and sorbitol there were no significant differences.

The aerial part dry mass confirms the smaller accumulation of biomass noted in M6 (105.0 $\mathrm{mg}), \mathrm{M} 7(111.0 \mathrm{mg})$ and M12 (74.0 mg) treatments. Therefore, the presence of the osmotic agents sorbitol and mannitol, as well as the highest concentration of sucrose tested, acted to suppress the metabolism of $A$. cearensis plants and their growth (Figure 3C).

Regarding root dry mass, there was an increase proportional to the rising concentrations of sucrose, in the media M1, M2, M3 and M4 (Figure 3D). These results corroborated those of other authors, who have reported an increase of root length and root dry mass with rising sucrose concentrations in the culture medium in various species (GEORGE, 2008; JO et al., 2009).

Contradictorily, the smallest root dry mass $(125 \mathrm{mg})$ was obtained in treatment M12, 


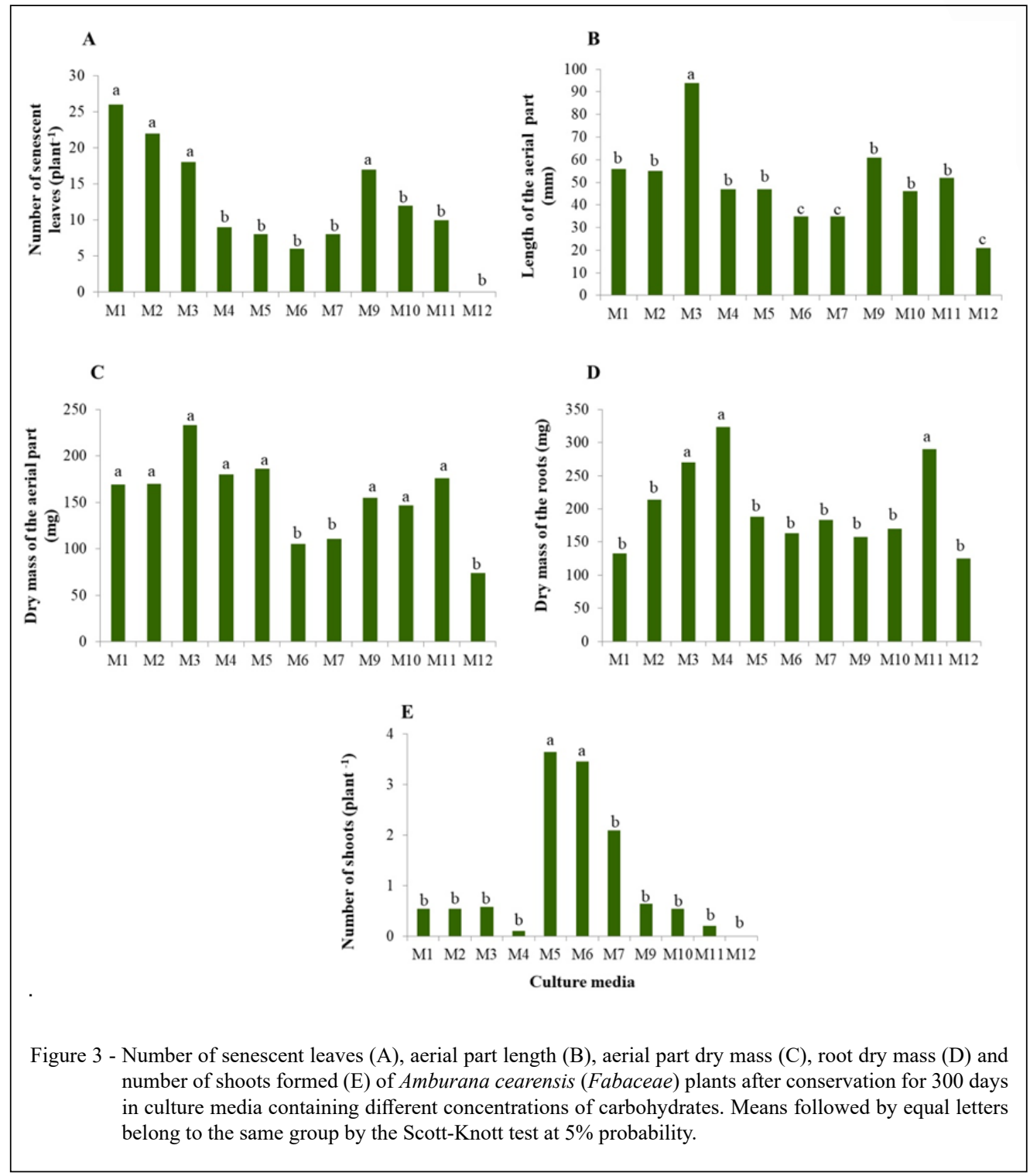

although this did not differ statistically from the values observed in M1, M2, M5, M6, M7, M9 and M10. Similar results were reported by FARIA et al. (2006), studying the effect of sucrose and sorbitol on Passiflora gibertii N.E.Br., where the smallest rooting percentages occurred in culture medium supplemented with sorbitol.

The plants also presented formation of lateral shoots, both at the base of the cotyledon and in the lateral buds, in all the treatments except M12 (262.92 mM of sucrose with $131.46 \mathrm{mM}$ of sorbitol, Figure 3E). The highest average numbers of shoots were produced by the plants in M5 (87.6 $\mathrm{mM}$ of sucrose with $43.8 \mathrm{mM}$ of mannitol) and M6
(131.46 mM of sucrose with $65.73 \mathrm{mM}$ of mannitol) treatments, with respective values of 3.64 and 3.45 shoots/plant (Figure 3E; Figure 2D).

\section{CONCLUSION}

The culture medium with $262.92 \mathrm{mM}$ of sucrose (M4) or the combination of $87.64 \mathrm{mM}$ of sucrose with $43.80 \mathrm{mM}$ of mannitol can be used for in vitro conservation of Amburana cearensis, by favoring the normal development of the preserved plants and resulting in better appearance, with predominance of uniform green leaves during the storage process for 10 months. 


\section{ACKNOWLEDGMENTS}

We thank Universidade Estadual de Feira de Santana (UEFS) for providing the physical support for the study, and the Coordenação de Aperfeiçoamento de Pessoal de Nível Superior (CAPES) for financial support (001) and for the postdoctoral research grant (PNPD/UEFS 15950830814) to the fourth author (T.L.S.).

\section{DECLARATION OF CONFLICT OF INTERESTS}

The authors declare no conflict of interest. The founding sponsors had no role in the design of the study; in the collection, analyses, or interpretation of data; in the writing of the manuscript, and in the decision to publish the results.

\section{AUTHORS' CONTRIBUTIONS}

All authors contributed equally for the conception and writing of the manuscript.

\section{REFERENCES}

AL-ABDALLAT, A. M. et al. In vitro preservation of transgenic tomato (Solanum lycopersicum L.) plants overexpressing the stress-related SIAREB1 transcription factor. International Journal of Molecular Sciences, v.18, p.1-19, 2017. Available from: $<$ https://www.ncbi.nlm.nih. gov/pmc/articles/PMC5535968/>. Accessed: Aug. 12, 2018.

ATTIA, O. A. et al. Ex situ preservation for some endemic and rare medicinal plants in Taif, KSA. Biotechnology \& Biotechnological Equipment, v.31, p.912-920, 2018. Available from: $<$ https://www. tandfonline.com/doi/full/10.1080/13102818.2017.1356690> Accessed: Sep. 12, 2019.

CAMPOS, V. C. A. et al. Micropropagation of umburana of cheiro. Ciência Rural, v.43, p.639-644, 2013. Available from: $\quad<$ http://www.scielo.br/scielo.php?script=sci_arttext\&pid $=$ S0103-84782013000400012>. Accessed: Jul. 15, 2018.

CHAUHAN, R. et al. In vitro slow-growth storage of Chlorophytum borivilianum Sant. et Fernand: a critically endangered herb. In vitro Cellular \& Developmental Biology - Plant, v.52, p.315321, 2016. Available from: <https://link.springer.com/content/ pdf/10.1007\%2Fs11627-016-9756-7.pdf >. Accessed: Mar. 14, 2018.

CUI et al. Sucrose-induced osmotic stress affects biomass, metabolite, and antioxidant levels in root suspension cultures of Hypericum perforatum L. Plant Cell, Tissue and Organ Culture, v.103, p.7-14, 2010. Available from: <https://link.springer.com/ content/pdf/10.1007\%2Fs11240-010-9747-z.pdf>. Accessed: Dec. $06,2017$.

EL-BAHR, M. K. et al. In vitro conservation of embryogenic cultures of date palm using osmotic mediated growth agents Journal of Genetic Engineering and Biotechnology, v.14, p.363-370, 2016. Available from: <https://www.sciencedirect com/science/article/pii/S1687157X16300233?via\%3Dihub>. Accessed: Sep. 07, 2019.

GEORGE, E. F. Plant Propagation by tissue culture procedure The Background. In: GEORGE, E.F., HALL, M.A., KLERK, G.J.
(Eds.). Plant propagation by tissue culture. 3.ed. Dordrecht, Springer, pp.1-28. 2008.

GRATTAPAGLIA, D., MACHADO, M.A. Micropropagação. In: TORRES, A.C., CALDAS, L.S., BUSO, J.A (Eds.), Cultura de tecidos e transformação genética de plantas, Embrapa - SPI / Embrapa - CNPH, Brasília, Brasil, p.183-260, 1998.

IUCN. IUCN Red List of Threatened Species, v.2019.2. Available from: <http:// www.iucnredlist.org>. Accessed: Sep. 09, 2019.

HUANG, H.-P. et al. Germplasm preservation in vitro of Polygonum multiflorum Thunb. Pharmacognosy Magazine, v.10, p.179-184, 2014. Available from: <https://www.ncbi.nlm.nih.gov/pubmed/24914285>. Accessed: Mar. 13, 2018. doi: 10.4103/0973-1296.131032.

JAIN, A. et al. Effect of carbendazim on in vitro conservation and genetic stability assessment in Curcuma longa and Zingiber officinale. Journal of Herbs, Spices \& Medicinal Plants, v.24, p.1-13, 2018. Available from: <https://www.tandfonline.com/doi/ abs/10.1080/10496475.2017.1423528>. Accessed: Mar. 17, 2018. doi: $10.1080 / 10496475.2017 .1423528$.

JO, E. A. et al. In vitro sucrose concentration affects growth and acclimatization of Alocasia amazonica plantlets. Plant Cell, Tissue and Organ Culture, v.96, p.307-315, 2009. Available from: <https://link.springer.com/article/10.1007/ s11240-008-9488-4>. Accessed: Aug. 14, 2018. doi: 10.1007/ s11240-008-9488-4.

KHAN, M. D. I. et al. In vitro conservation strategies for the Indian willow (Salix tetrasperma Roxb.), a vulnerable tree species via propagation through synthetic seeds. Biocatalysis and Agricultural Biotechnology, v.16, p.17-21, 2018. Available from: <https:// www.sciencedirect.com/science/article/pii/S1878818118300045>. Accessed: Mar. 13, 2018. doi: 10.1016/j.bcab.2018.07.002.

LATALIZA, A. A. B. et al. Antioxidant, cytotoxic, antiproliferative and acetylcholinesterase inhibition properties of the extract from Amburana cearensis. Journal of Multidisciplinary Engineering Science and Technology, v.6, p.9336-9343, 2019.

LEITE, E. J. 2005. State-of-knowledge Amburana cearensis (Fr. Allem.) A.C. Smith (Leguminosae: Papilionoideae) for genetic conservation in Brazil. Journal for Nature Conservation, v.13, p.49-65, 2005. Available from: <https://www.sciencedirect.com/ science/article/pii/S1617138105000026> . Accessed: Jul. 17, 2018. doi: 10.1016/j.jnc.2004.07.003.

LLOYD, G., MCCOWN, B. Use of microculture for production and improvement of Rhododendronn ssp. HortScience. v.15, p.415-417, 1980 .

MUÑOZ, M.; et al. Slow growth in vitro culture for conservation of Chilotanum potato germplasm. Chilean Journal of Agricultural Research. v.79, 26-34. Available from: $\quad<$ https://scielo.conicyt.cl/scielo.php?script=sci_arttext\&p id $=$ S0718-58392019000100026>. Accessed: Sep. 7, 2019. doi: $10.4067 / \mathrm{S} 0718-58392019000100026$.

NASIRUDDIN AND ISLAM. In vitro slow-growth conservation for two genotypes of Solanum tuberosum L. M. Bangladesh Journal of Botany, v.47, p.369-380, 2018. Available from: $<$ https://www.researchgate.net/publication/327767710_In_vitro_ slow-growth_conservation_for_two_genotypes_of_Solanum tuberosum_L.>. Accessed: Sep. 07, 2019. 
PEREIRA, E. P. L. et al. Amburana cearensis seed extracts protect PC-12 cells against toxicity induced by glutamate. Brazilian Journal of Pharmacognosy, v.27, p.199-205, 2017. Available from: <https:// www.sciencedirect.com/science/article/pii/S0102695X16304525>. Accessed: Mar. 13, 2018. doi: 10.1016/j.bjp.2016.08.010.

SÁ, M.B. et al. Phytochemistry and preliminary assessment of the antibacterial activity of chloroform extract of Amburana cearensis (Allemão) A.C. Sm. against Klebsiella pneumonia CarbapenemaseProducing Strains. Evidence-Based Complementary and Alternative Medicine, v.2014, p.1-7, 2014. Available from: $<$ https://www.ncbi.nlm.nih.gov/pubmed/24772183>. Accessed: Aug. 22, 2018. doi: 10.1155/2014/786586.

SHARAF, S. A. et al. Slow-growth preservation of wild shih (Artemisia herba-alba Asso.) microshoots from Jordan. Journal of Food, Agriculture and Environment, v.10, p.1359-1364, 2012.
SUMARYONO et al. Effect of carbohydrate source on growth and performance of in vitro sago palm (Metroxylon sagu Rottb.) plantlets. Hayati Journal of Biosciences, v.19, p.88-92, 2012. Available from: <https:/www.sciencedirect.com/science/article/ pii/S1978301916301383>. Accessed: Sep, 16, 2018. doi: 10.4308/ hjb.19.2.88.

TAKUR, S. et al. In vitro approaches for conservation of Asparagus racemosus Willd. In vitro Cellular \& Developmental Biology Plant, v.51, p.619-625, 2015. Available from: <https://link.springer. com/article/10.1007/s11627-015-9706-9>. Accessed: Aug. 22, 2018.

TAVAZZA, R. et al. A validated slow-growth in vitro conservation protocol for globe tichoke germplasm: A cost-effective tool to preserve from wild to elite genotypes. Scientia Horticulturae, v.197, p.135-143, 2015. Available from: <https://www.sciencedirect.com/ science/article/pii/S0304423815301886>. Accessed: Sep. 16, 2018. 